\title{
Gambaran kadar hemoglobin pada pekerja bangunan
}

\author{
${ }^{1}$ Valerie I. R. Gunadi \\ ${ }^{2}$ Yanti M. Mewo \\ ${ }^{2}$ Murniati Tiho
}

\author{
${ }^{1}$ Kandidat Skripsi Fakultas Kedokteran Universitas Sam Ratulangi Manado \\ ${ }^{2}$ Bagian Biokimia Fakultas Kedokteran Universitas Sam Ratulangi Manado \\ Email: gunadivalerie@gmail.com
}

\begin{abstract}
Hemoglobin is a red blood cells protein that has an important role to transport the oxygen, carbon dioxide and proton in human body. Physical activity can affect hemoglobin level. Physical activity with moderate to vigorous intensity can cause the change of hemoglobin level in human body. One of the jobs with moderate to vigorous physical activity is labor. The purpose of this study was to find out the description of hemoglobin level in labor. The study used was descriptive cross sectional study. The respondents of this study were 30 men that worked as a labor that agreed to be a respondent and in inclusion and exclusion criteria. The total sampling method was used to chose the samples. The result showed 28 subjects $(93,4 \%)$ with normal hemoglobin level $(13,2-17,3 \mathrm{~g} / \mathrm{dL}), 1$ subject $(3,3 \%)$ with low hemoglobin levels, and 1 subject $(3,3 \%)$ with high hemoglobin level. Conclusion: Based on the result, it can be concluded that hemoglobin level in labor is mostly $(93,4 \%)$ in normal level.
\end{abstract}

Keywords: hemoglobin level, labor.

\begin{abstract}
Abstrak: Hemoglobin merupakan protein sel darah merah yang memiliki peranan penting dalam proses transport oksigen, karbondioksida serta proton dalam tubuh. Aktivitas fisik yang dilakukan seseorang dapat berpengaruh terhadap kadar hemoglobin dalam tubuh. Aktivitas fisik dengan intensitas sedang sampai berat dapat menyebabkan kadar hemoglobin dalam tubuh berubah. Salah satu pekerjaan dengan aktivitas fisik sedang sampai berat ialah pekerja bangunan. Tujuan dari penelitian ini adalah untuk mengetahui gambaran kadar hemoglobin pada pekerja bangunan. Penelitian yang digunakan bersifat deskriptif dengan pendekatan cross sectional. Sampel dalam penelitian ini berjumlah 30 orang pekerja bangunan yang sesuai kriteria inklusi dan eksklusi dan bersedia menjadi responden. Metode pemilihan sampel menggunakan cara total sampling. Hasil penelitian didapatkan respoden yang memiliki kadar hemoglobin normal $(13,2-17,3 \mathrm{~g} / \mathrm{dL})$ sebanyak 28 orang $(93,4 \%), 1$ orang $(3,3 \%)$ memiliki kadar hemoglobin yang kurang dari nilai normal, dan 1 orang $(3,3 \%)$ memiliki kadar hemoglobin yang lebih dari nilai normal. Simpulan: Dari hasil penelitian, dapat disimpulkan bahwa gambaran kadar hemoglobin pada pekerja bangunan sebagian besar $(93,4 \%)$ memiliki kadar hemoglobin normal.
\end{abstract}

Kata kunci: kadar hemoglobin, pekerja bangunan.

Darah terdiri dari dua komponen, yakni komponen cair yang disebut plasma dan komponen padat yaitu sel-sel darah. ${ }^{1}$ Sel darah terdiri atas tiga jenis yaitu eritrosit, leukosit dan trombosit. ${ }^{2}$

Eritrosit memiliki fungsi yang sangat penting dalam tubuh manusia. Fungsi terpenting eritrosit ialah transport $\mathrm{O}_{2}$ dan $\mathrm{CO}_{2}$ antara paru-paru dan jaringan. Suatu protein eritrosit yaitu hemoglobin $(\mathrm{Hb})$ memainkan peranan penting pada kedua proses transport tersebut. ${ }^{2}$ 
Hemoglobin merupakan suatu protein tetramerik eritrosit yang mengikat molekul bukan protein, yaitu senyawa porfirin besi yang disebut heme. Hemoglobin mempunyai dua fungsi pengangkutan penting dalam tubuh manusia, yakni pengangkutan oksigen ke jaringan dan pengangkutan karbondioksida dan proton dari jaringan perifer ke organ respirasi. ${ }^{3}$

Nilai batas normal kadar $\mathrm{Hb}$ menurut World Health Organization 2001 yaitu untuk umur 5-11 tahun $<11,5 \mathrm{~g} / \mathrm{dL}$, umur 12-14 tahun $\leq 12,0 \mathrm{~g} / \mathrm{dL}$ sedangkan diatas 15 tahun untuk perempuan $>12,0 \mathrm{~g} / \mathrm{dL}$ dan laki-laki > 13,0 g/dL. ${ }^{4}$ Kadar $\mathrm{Hb}$ dalam darah dapat dipengaruhi oleh beberapa faktor, salah satunya aktivitas fisik. ${ }^{5}$

Aktivitas fisik yang dilakukan manusia akan berpengaruh terhadap peningkatan atau penurunan kadar hemoglobin dalam darah. ${ }^{5}$ Aktivitas fisik terbagi atas aktivitas fisik ringan, aktivitas fisik sedang dan aktivitas fisik berat. ${ }^{6}$ Aktivitas fisik yang dapat mempengaruhi kadar $\mathrm{Hb}$ ialah aktivitas fisik intensitas sedang hingga berat. ${ }^{7}$ Perubahan kadar $\mathrm{Hb}$ melalui aktivitas fisik sedang sampai berat, dihipotesiskan terjadi karena perubahan volume plasma, perubahan $\mathrm{pH}$, dan hemolisis intravaskular. ${ }^{8,9}$

Saat melakukan aktivitas fisik seperti berolahraga akan terjadi peningkatan aktivitas metabolik yang tinggi, asam yang diproduksi berupa ion hidrogen dan asam laktat akan semakin banyak, hal ini akan menyebabkan terjadinya penurunan $\mathrm{pH}$. Afinitas antara oksigen dan hemoglobin akan menurun apabila $\mathrm{pH}$ darah rendah. Apabila afinitas tarik antara oksigen dan hemoglobin menurun, maka hemoglobin akan melepaskan lebih banyak oksigen sehingga meningkatkan pengiriman oksigen ke otot. ${ }^{5}$

Sebagai bentuk dari adaptasi tubuh terhadap aktivitas intensitas sedang - berat yang dilakukan, dapat terjadi perubahan pada volume plasma darah dimana volume plasma akan menurun dan akan membuat kadar hemoglobin dalam darah terlihat meningkat, selain itu saat melakukan aktivitas intensitas sedang - berat, tubuh membutuhkan oksigen lebih banyak, untuk mengkompensasi kebutuhan oksigen, tubuh akan melakukan eritropoiesis yang juga akan membuat kadar $\mathrm{Hb}$ meningkat. ${ }^{8}$ Latihan fisik berat yang dilakukan secara terus-menerus dan dengan durasi yang lama dapat menyebabkan penurunan massa sel darah merah dengan cara hemolisis intravaskular, hemolisis intravaskular disebabkan oleh ruptur mekanik dinding sel eritrosit yang terjadi ketika sel darah merah melewati kapiler-kapiler darah dari otot otot yang berkontraksi, hal tersebut dapat berpengaruh terhadap penurunan kadar $\mathrm{Hb}^{9}$

Penelitian yang dilakukan oleh Moosavizademonir tahun 2011 dengan sampel 13 atlet wanita yang melakukan latihan aerobik selama delapan minggu, didapatkan hasil yakni terjadi penurunan kadar $\mathrm{Hb}^{10}$ Penelitian serupa dilakukan oleh Halim tahun 2014 dengan sampel 20 mahasiswi Program Studi Ilmu Keperawatan Universitas Sam Ratulangi Manado angkatan 2013, didapatkan hasil yakni terjadi penurunan kadar hemoglobin sesudah latihan zumba selama dua minggu. Walaupun intensitas latihan zumba ini termasuk dalam intensitas sedang tetapi pada subjek penelitian yang tidak rutin berolahraga dapat dianggap termasuk dalam intensitas berat. ${ }^{11}$

Salah satu pekerjaan dengan aktivitas fisik intensitas sedang sampai berat adalah pekerja bangunan. Pekerja bangunan merupakan sekumpulan pekerja yang memiliki keterampilan untuk membangun suatu bangunan. Dalam pelaksanaan pekerjaan, tenaga kerja dibagi beberapa bagian seperti: tenaga kerja ahli, mandor, tenaga tukang (tukang besi, tukang batu, tukang kayu, tukang las dan tukang listrik), tenaga kasar, dan tenaga keamanan. ${ }^{12}$

Berdasarkan uraian di atas, penulis tertarik untuk melakukan penelitian mengenai gambaran kadar hemoglobin pada pekerja bangunan di area pembangunan gedung kuliah Fakultas Kedokteran Universitas Sam Ratulangi. 


\section{METODE PENELITIAN}

Penelitian ini bersifat deskriptif dengan pendekatan cross sectional. Penelitian ini dilaksanakan mulai bulan Agustus 2016 hingga Desember 2016 di area pembangunan gedung kuliah Fakultas Kedokteran Universitas Sam Ratulangi. Sampel dalam penelitian ini berjumlah 30 orang yang sesuai kriteria inklusi yaitu pekerja bangunan dengan aktivitas fisik intensitas berat di Fakultas Kedokteran Universitas Sam Ratulangi, Bersedia mengikuti penelitian dengan mengisi dan menandatangani informed consent dan sehat. Metode pemilihan sampel menggunakan cara total sampling.

Pemeriksaan kadar hemoglobin darah diambil melalui darah vena (fossa cubiti), responden tidak puasa. Sampel darah yang diperoleh dibawa ke laboratorium Kanaka dan diperiksa dengan menggunakan alat Sysmex XS-800i. Data diolah dengan menggunakan Microsoft Office Excel 2007.

\section{HASIL PENELITIAN}

Responden berjumlah 30 orang, seluruhnya berjenis kelamin laki - laki dengan rentang usia 18 tahun - 51 tahun.

Tabel 1. Distribusi responden berdasarkan kadar hemoglobin

\begin{tabular}{ccc}
\hline $\begin{array}{c}\text { Kadar } \\
\text { Hemoglobin }\end{array}$ & Jumlah & $\mathbf{( \% )}$ \\
$<13,2 \mathrm{~g} / \mathrm{dL}$ & 1 orang & $3,3 \%$ \\
$13,2-17,3 \mathrm{~g} / \mathrm{dL}$ & 28 orang & $93,4 \%$ \\
$>17,3 \mathrm{~g} / \mathrm{dL}$ & 1 orang & $3,3 \%$ \\
Total & $\mathbf{3 0}$ Orang & $\mathbf{1 0 0 \%}$ \\
\hline
\end{tabular}

Hasil pemeriksaan kadar hemoglobin didapatkan nilai maksimum $17,5 \mathrm{~g} / \mathrm{dL}$, nilai minimum 11,8 g/dL, nilai median 15,25 $\mathrm{g} / \mathrm{dL}$, dan nilai rata-rata $15,18 \mathrm{~g} / \mathrm{dL}$ dengan standar deviasi 1,105.

Hasil penelitian pada pada pekerja bangunan didapatkan sebagian besar responden yaitu 28 orang $(93,4 \%)$ memiliki kadar hemoglobin yang normal (Tabel 1).

\section{BAHASAN}

Berdasarkan hasil penelitian yang telah dilakukan, terdapat 28 orang responden memiliki kadar hemoglobin yang berada dalam batas normal, satu orang responden memiliki kadar hemoglobin yang lebih rendah daripada nilai rujukan normal, dan satu orang responden memiliki kadar hemoglobin yang lebih tinggi daripada nilai rujukan normal.

Penelitian yang dilakukan serupa dengan penelitian yang dilakukan Kosasi tahun 2013 pada mahasiswa anggota UKM pendekar Universitas Andalas yang memiliki indeks massa tubuh normal dan tidak merokok yang rutin melakukan kegiatan bela diri setiap minggunya sebanyak 3 kali dengan durasi lebih kurang $2-2,5$ jam, dengan jumlah 28 orang dan didapatkan hasil kadar hemoglobin normal. $^{5}$

Kadar hemoglobin dipengaruhi oleh beberapa faktor seperti usia dan jenis kelamin, bertempat tinggal di dataran tinggi, merokok, aktivitas fisik dan nutrisi. Aktivitas fisik sehari - hari dan latihan jasmani atau olahraga yang dilakukan seseorang dapat mempengaruhi kadar hemoglobin. Pada individu yang melakukan latihan fisik secara rutin kadar hemoglobinnya akan sedikit naik, sedangkan akan didapatkan menurun pada orang dengan aktivitas fisik intensitas berat yang dilakukan secara terus-menerus seperti yang dilakukan oleh pekerja bangunan. ${ }^{9,13}$

Hasil penelitian didapatkan sebagian besar responden yang merupakan pekerja bangunan memiliki kadar hemoglobin yang berada dalam batas normal. Keadaan ini dapat dipengaruhi oleh asupan nutrisi serta kebiasaan merokok dari responden, sehingga walaupun aktivitas fisik yang dilakukan pekerja bangunan termasuk dalam intensitas berat, kadar hemoglobinnya dapat terlihat normal.

Asupan nutrisi dalam hal ini zat besi dan protein diperlukan untuk sintesis hemoglobin. ${ }^{13}$ Penelitian yang dilakukan oleh Nurnia tahun 2013 mengenai hubungan pola konsumsi dengan status hemoglobin anak sekolah dasar yang dilakukan pada 141 anak sekolah dasar, didapatkan adanya hubungan yang 
signifikan antara konsumsi makanan sumber zat besi heme dengan kadar hemoglobin, didapatkan sebanyak $62,4 \%$ anak memiliki kadar hemoglobin normal. ${ }^{14}$

Responden dalam penelitian ini semuanya merupakan perokok. Perokok dibagi atas tiga kategori, yaitu perokok ringan (1-10 batang perhari), perokok sedang (11-20 batang perhari) dan perokok berat (lebih dari 20 batang perhari). ${ }^{15}$ Merokok dapat menyebabkan masuknya zat-zat berbahaya bagi tubuh, salah satunya adalah karbonmonoksida (CO). Pada perokok berat, tingkat karbonmonoksida dalam tubuh menjadi meningkat. Hemoglobin memiliki afinitas yang tinggi terhadap karbonmonoksida, keadaan ini mengakibatkan pengikatan oksigen dengan hemoglobin menjadi berkurang dan oksigen tidak dapat ditransport hemoglobin ke organ dan jaringan yang membutuhkan. ${ }^{16}$ Keadaan tersebut akan direspon tubuh dengan melakukan mekanisme kompensasi yakni proses hematopoiesis sehingga produksi hemoglobin akan meningkat. ${ }^{17}$

Penelitian lain yang dilakukan oleh Moosavizademonir tahun 2011 dengan sampel 13 atlet wanita yang melakukan latihan aerobik selama delapan minggu, didapatkan hasil yakni terjadi penurunan kadar Hb. ${ }^{10}$ Penelitian serupa yang dilakukan oleh Halim tahun 2014 dengan sampel 20 mahasiswi Program Studi Ilmu Keperawatan Universitas Sam Ratulangi Manado angkatan 2013, didapatkan hasil yakni terjadi penurunan kadar hemoglobin sesudah latihan zumba selama dua minggu. Walaupun intensitas latihan zumba ini termasuk dalam intensitas sedang tetapi pada subjek penelitian yang tidak rutin berolahraga dapat dianggap termasuk dalam intensitas berat. ${ }^{11}$

Penurunan kadar hemoglobin dihubungkan dengan aktivitas fisik berat yang dilakukan secara terus-menerus dan dengan durasi yang lama, hal ini dapat menyebabkan hemolisis intravaskular dan dapat menyebabkan terjadinya penurunan massa sel darah merah, hal tersebut dapat berpengaruh terhadap penurunan kadar
Hb. ${ }^{9}$ Selain itu aktivitas fisik berat yang dilakukan secara terus-menerus dapat memicu terjadinya ketidakseimbangan antara produksi radikal bebas dan stres oksidatif, apabila tubuh berada dalam kondisi stres oksidatif, radikal bebas akan menyebabkan terjadinya peroksidasi lipid membrane sel dan akan merusak membran sel. ${ }^{18,19}$ Peroksidasi lipid membran sel akan menyebabkan mudahnya sel eritrosit mengalami hemolisis. Hemolisis yang terjadi pada membran eritrosit akan menyebabkan hemoglobin terbebas sehingga dapat menyebabkan penurunan kadar hemoglobin. ${ }^{20}$

Suatu penelitian yang dilakukan oleh Ewangga tahun 2015 dengan sampel mahasiswa fakultas kedokteran Universitas Islam Bandung tahun akademik 2014/2015 yang dibagi menjadi dua kelompok yaitu pemain futsal dan tidak berolahraga, dimana masing-masing kelompok berjumlah 23 orang sampel, didapatkan hasil kadar hemoglobin pada pemain futsal lebih tinggi dibandingkan dengan yang tidak berolahraga. $^{21}$ Demikian pula penelitian yang dilakukan oleh Tiopi tahun 2008 dengan sampel siswi SMA negeri 1 Rengat. Penelitian ini terdiri dari kelompok senam high impact dan kelompok senam low impact yang masing -masing kelompok terdiri dari 31 subjek. Didapatkan hasil terdapat perbedaan yang signifikan kenaikan $\mathrm{Hb}$ antara kelompok senam high impact dan kelompok senam low impact. ${ }^{22}$

Peningkatan kadar hemoglobin berhubungan dengan aktivitas fisik dihipotesiskan terjadi seiring dengan perubahan volume plasma ketika melakukan latihan fisik. Perubahan volume plasma ketika melakukan aktivitas fisik akan menyebabkan terjadinya penurunan relatif hemoglobin dan konsentrasi oksigen dalam darah arteri, sehingga akan merangsang terjadinya eritropoiesis. Selain itu, pada saat melakukan aktivitas fisik, tubuh akan mengalami kehilangan cairan tubuh karena keringat, hal ini menyebabkan terjadinya penurunan volume plasma sehingga terjadi peningkatan kadar hemoglobin secara relatif. ${ }^{8,23}$ 
Limitasi penelitian ini yaitu peneliti tidak bisa mengontrol hal-hal yang dapat memengaruhi data seperti makanan yang dikonsumsi dan kebiasaan merokok. Selain itu jumlah sampel yang diambil tidak mencukupi sesuai dengan total sampling yaitu 47 sampel karena hanya 30 sampel yang bersedia dijadikan subjek penelitian sehingga response rate dari penelitian ini ialah sebesar $60 \%$.

\section{SIMPULAN}

Berdasarkan hasil penelitian dapat disimpulkan bahwa kadar hemoglobin pada sebagian besar pekerja bangunan berada dalam batas normal.

\section{SARAN}

1. Untuk responden yang memiliki hasil kadar hemoglobin yang normal disarankan untuk mempertahankan kadar hemoglobinnya dengan mengonsumsi makanan yang sehat, melakukan aktivitas fisik yang tidak berlebihan serta memulai dan menjaga gaya hidup sehat.

2. Untuk responden yang memiliki hasil kadar hemoglobin yang berada dibawah nilai normal, disarankan untuk memperhatikan asupan nutrisi, tidak melakukan aktivitas fisik berat secara berlebihan serta menjaga gaya hidup sehat.

3. Untuk responden yang memiliki hasil kadar hemoglobin yang berada diatas nilai normal, disarankan untuk melakukan pemeriksaan lebih lanjut, memperhatikan asupan nutrisi, aktivitas fisik, serta kebiasaan merokok.

\section{UCAPAN TERIMA KASIH}

Ucapan terima kasih disampaikan kepada pekerja bangunan di area pembangunan gedung kuliah Fakultas Kedokteran Universitas Sam Ratulangi Manado, Laboratorium Kanaka, dan semua pihak yang terlibat langsung maupun tidak langsung dalam pelaksanaan penelitian, maupun dalam penyusunan artikel sehingga penulis bisa menyelesaikan artikel ini.

\section{DAFTAR PUSTAKA}

1. Physiologi web. Physiologi illustratrion: whole blood is composed of plasma and formed elements. Available From:

http://www.physiologyweb.com/figur es/physiology_illustration_whole_blo od_is_composed_of_plasma_and_for med_elements.html. 2015. Accesed on: September $14^{\text {th }} 2016$.

2. Koolman J, Rohm KH. Atlas berwarna dan teks biokimia. Jakarta: Hipokrates; 2001. h. 244-54.

3. Kennelly PJ, Rodwell VW. Protein: mioglobin dan hemoglobin. Dalam: Murray RK, Granner DK, Rodwell VW, Editor. Biokimia harper. Edisi ke 27. Pendit BU, alih bahasa Indonesia. Wulandari N, editor edisi bahasa Indonesia. Jakarta: penerbit buku kedokteran EGC; 2009. p. 4452.

4. Sadikin M. Biokimia darah. Jakarta: Widya Medika; 2002. h. 25-39.

5. Kosasi L, Oenzil F, Yanis A. Hubungan aktivitas fisik terhadap kadar hemoglobin pada mahasiswa anggota UMK pandekar universitas andalas. Jurnal Kesehatan Andalas. 2014;3(2).

6. Chan TH. Examples of moderate and vigorous physical activity. https://www.hsph.harvard.edu/besityprevention-source/moderate-andvigorous-physical-activity/. Accesed on: September $16^{\text {th }} 2016$.

7. Santoso G. Manajemen keselamatan dan kesehatan kerja. Jakarta: Prestasi Pustaka; 2004.

8. Dolan LB, Gelmon K, Courneya KS, Mackey JR, Segal RJ, Lane K, et al. Hemoglobin and aerobics fitness change with superviced exercise training in breast cancer patiens receiving chemotherapy. Cancer Epidemiol Biomarkers and Preventive. 2010;19:2826-32.

9. Mairbaurl H. Red blood cells in sports: effect of exercise and training on oxygen supply by red blood cells. Frontiers in Physiology. 2013;4:1-2.

10.Moosavizademonir. Effect of one period training on hemoglobin, hematocrit and rbc of athlete girls. Annals of Biological Research. 2011;2(6):6424. 
11.Halim EV, Ticoalu SHR, Wongkar D. Pengaruh latihan zumba terhadap kadar hemoglobin. Jurnal eBiomedik. 2014;2(1).

12.Ahadi. Tenaga kerja proyek bangunan. Available From: http:// www.ilmusipil.com/tenaga-kerjaproyek-bangunan. 2011. Accesed on: September $16^{\text {th }} 2016$.

13.Juanda M. Perbedaan kadar hemoglobin antara mahasiswa yang rutin berolahraga futsal pada fakultas pendidikan olahraga dan kesenian IKIP dengan mahasiswa yang jarang berolahraga pada fakultas keguruan ilmu pengetahuan IKIP periode Januari 2013 - Oktober 2013 [Skripsi]. Mataram: Universitas Ikip Mataram; 2013.

14.Nurnia, Hadju V, Kesumasari C. Hubungan pola konsumsi dengan status hemoglobin anak sekolah dasar di wilayah pesisir Kota Makassar. Jurnal Media Kesehatan Masyarakat Indonesia. 2013.

15.Bustan MN. Epidemiologi Penyakit Tidak Menular. Edisi kedua. Jakarta: Rineka Cipta. 2007.

16. Vajpayee N, Graham SS, Bem S. Basic examination of blood and bone marrow. In : McPherson RA, Pincus MR, eds. Henry's clinical diagnosis and mangement by laboratory methods. $22^{\text {nd }}$ ed. Philadelphia, PA : Saunders, an imprint of Elsevier Inc; 2011. p. 509-35.

17.Zukefeli AAB. Hubungan Merokok Dengan Kadar Hemoglobin Pada Warga
Dengan Jenis Kelamin Laki-Laki Berusia 18-40 Tahun Yang Tinggal Di Bandar Putra Bertam, Kepala Batas, Pulau Pinang, Malaysia. [skripsi]. Medan: Universitas Sumatera Utara; 2010.

18.Sianturi AC. Pengaruh pemberian ekstrak air daun bangun - bangun (Coleus ambonicus L) terhadap jumlah sel darah merah dan hemoglobin pada tikus putih (Rattus norvegicus) yang diberi aktivitas fisik maksimal [Skripsi]. Medan: Universitas Negeri Medan; 2011.

19.Evans WJ. Vitamin e, vitamin $\mathrm{c}$ and exercise. Am $\mathbf{J}$ Clin Nutr. 2000;72:647S-52S.

20.Saputro DA, Junaidi S. Pemberian vitamin c pada latihan fisik maksimal dan perubahan kadar hemoglobin dan jumlah eritrosit. Journal of Sport Sciences and Fitness. 2015;4(3).

21.Ewangga B, Akbar IB, Nilapsari R. Perbedaan kadar hemoglobin yang berolahraga dan tidak berolahraga. Bandung: Universitas Islam Bandung Repository. 2015. h. 172.

22.Tiopi DI. Pengaruh senam aerobik terhadap kadar hemoglobin pada siswi SMA Negeri 1 rengat [Thesis]. Padang: Universitas Andalas Padang; 2008.

23. Wirnitzer KC, Faulhaber $M$. Hemoglobin and hematocrit during an 8 day mountain bike race: a field study. Journal of Sports Science and medicine.

2007;6:265-6 